DOI https://doi.org/10.32782/2305-9389/2020.23.25

УДК 35.08:17.023(075.8)

Пержун Володимир,

кандидат сочіологічних наук,

дочент кафедри філософії та культурології

Чернівецького національного університету імені Юрія Федьковича, докторант кафедри суспільних відносин і суспільно-владних зв'язків Національної академії державного управління при Президентові України

\title{
ДОСЛІДЖЕННЯ УПРАВЛІНСЬКОЇ КУЛЬТУРИ: ІСТОРІЯ ТА ПЕРСПЕКТИВИ В УМОВАХ ПЕРЕХОДУ ДО ПУБЛІЧНОГО УПРАВЛІННЯ В УКРАЇНІ
}

Сучасний етап управління суспільством і державою складний, неоднозначний, до того ж перебуває $i$ знаходиться на етапі серйозних змін українського соціуму в усіх сферах суспільного життя. Він потребує нових підходів модернізації управління, розуміння історично глибинних, найважливіших, вирішальних проблем управління та з'ясування ролі в цій стратегічній роботі управлінської культури. Шляхи розвитку й структурні зміни управління всіх рівнів торкнулися й державного управління, шьо поступово має трансформуватися в більш відкрите в діалозі з громадянським суспільством, має ставати публічним. Окреслені зміни й перетворення зумовлюють і сприяють прочесам результативного підходу до проблем досліджень історії та сучасних напрямів формування, розвитку, осмислення управлінської культури. Найбільше ицей процес пов'язаний із реальним життям суспільства, держави, владних структур, інститутів громадянського суспільства, дієвої соціальної співпраці держави і громадянського суспільства тощо. Власне від названих чинників істотно залежали й залежать формування складових ознак і якостей управлінської культури, ї̈ місие і роль у державному (публічному) управлінні.

Усвідомлюємо, щсо управлінець, який починає виконувати управлінську роботу, вже має деякі сформовані якості управлінської культури. Її формування, а надалі розвиток, становлення та утвердження відбуваються в різноманітних соціокультурних обставинах, сочцільному оточенні, у відносинах із колегами, керівництвом, загалом соиіумом. До того ж сучасні прочеси формування управлінської культури мають як організований, так і стихійний характер. А власне від циих обставин істотно залежить професійна діяльність і робота публічного управліния. Ми розумісмо управлінську культуру як сочіально-політичний та державно-управлінський феномен, навіть більше, вона в прочесі свого історичного формування й розвитку структурувалася в самодостатній суспільно-державний інститут, який має вплив на управлінську політику державою, суспільством, різноманітними колективами, територіальними громадами і т. д. Таким складним питанням історії і сучасним перспективам формування та дієвості управлінської культури в публічному управлінні присвячена ияя стаття.

Ключові слова: управлінська культура, публічне управління, суспільство, держава, розвиток, цінності, технології управління.

\section{Perzhun Volodymyr. Research of management culture: history and prospects in the condition of transition to public governance in Ukraine}

The current stage of governance of society and the state is complex, ambiguous, in addition, is and is at the stage of serious changes in Ukrainian society in all spheres of public life. It requires new approaches to modernization of management, understanding of historically deep, most important, crucial problems of management and what is the role of managerial culture in this strategic work. Ways of development and structural changes in governance at all levels also affected public administration, which should gradually be transformed into a more open one in dialogue with civil society and become public. The outlined changes and transformations determine and promote the processes of effective approach to the problems of research of history and modern directions of formation, development, comprehension of managerial culture. This process is mostly related to the real life of society, the state, government agencies, civil society institutions, effective social cooperation between the state and civil society, and so on. In fact, the formation of the constituent features and qualities of managerial culture, its place and role in public (public) management largely depended on these factors.

We realize that a manager who begins to perform managerial work already has some established qualities of management culture. Its formation, and further development, formation and establishment takes place in various sociocultural circumstances, social environment, in relations with their colleagues, management, society in general. In addition, modern processes of forming a management culture are both organized and spontaneous. In fact, the professional activity and work of a public manager largely depend on these circumstances. We understand managerial culture as a sociopolitical and public-administrative phenomenon, even more, it, in the process of its historical formation and development was structured into a self-sufficient public institution, which has an impact on management policy by the state, society, various groups, local communities and etc. This article is devoted to such complex issues of history and modern prospects of formation and effectiveness of management culture in public administration.

Key words: managerial culture, public administration, society, state, development, values, management technologies. 
Найперше, що хотілося б зауважити стосовно історичних витоків і перспективних напрямів дослідження управлінської культури, - це її роль, значення й практичне застосування у здоровій регулятивній політиці, яка має стосуватися різноманітної управлінської роботи. Ефективне, а найголовніше, результативне управління повноцінно має забезпечувати, задовольняти, а також регулювати життєдіяльність суспільства, державних інституцій, органів місцевого самоврядування, інститутів громадянського суспільства, трудових колективів і т. ін. Окрім цього, важливо також говорити про помітний вплив важелів і принципів управління як практичної діяльності загалом на сприйняття й використання суспільних цінностей у процесі самого управління. Адже здорові цінності тільки сприятимуть результативній практичній роботі управлінців різних рівнів. Такими цінностями можуть виступати: освіта; професіоналізм і компетентність у роботі; управлінські знання і навички; здорова, повноцінна сім'я; сформований світогляд; толерантність і людяність; принциповість; повага до свого колективу; комунікабельність; справедливість вирішення спірних питань; поведінкові ефекти тощо.

Нагадаємо, що сам феномен управлінської культури історично формувався як окомір управлінської діяльності, який своїми важелями і характеристиками допомагав би управлінцям у прийнятті зважених і вірних рішень, розумінні ними їхньої здатності до важкої праці управлінця, зрештою, чи покликані вони до цього. Про таку характеристику управлінської культури писали відомі дослідники цієї проблематики - М. Вебер, Л. Гумплович, Ф. Тейлор, А. Файоль, К. Левін, Р. Лайкерт, В. Вільсон, Б. Скінер, Г. Райт та ін. Вони залишаються актуальними і нині. Звичайно, варто наголосити, що 3 плином соціально-історичного часу змінювалися підходи до формування управлінської культури, з'являлися інші моделі використання якостей, ознак і принципів управлінської культури, які виходили й базувалися на нових соціальних, управлінських, політичних, соціокультурних технологіях. Описували й давали практичні рекомендації щодо їх застосування Д. Норт, Г. Саймон, Д. Хелд, Д. Белл, Р. Каплан, І. Валлерстайн, М. Сміт, М. Армстрогн, Б. Амарджані, Д. Креймс, А. Хойзер та ін. Крім того, змінювалися методологічні підходи та методи дослідження управлінської культури.

У цьому ж науковому полі - пошуку нових напрямів дослідження управлінської культури - працюють і українські вчені: А. Колодій займається подальшою розробкою методології та методів дослідження галузі публічного управління; В. Бакуменко вивчає нові доробки у сфері державно-управлінських рішень; Л. Гонюкова досліджує політичні партії в державно-управлінській моделі; Л. Пашко аналізує й оцінює людські ресурси в державному управлінні; Р. Войтович дописує про стилі діяльності і культуру управлінців; О. Петроє вивчає проблеми соціального діалогу в державному управлінні; Ю. Сурмін досліджує методологію науки «державне управління»; О. Орлов описує сучасні інновації в державному управлінні; Н. Нижник доводить значення теоретичних й практичних засад управлінської культури; В. Козаков порушує питання соціально-ціннісних аспектів державного управління; А. Гошко зазначає роль управлінської культури в системі місцевого самоврядування; М. Пірен акцентує на управлінській культурі владної еліти та ін.

Сучасні реалії актуалізують розуміння й успішного вирішення проблем значимості управлінської культури управлінців місцевого самоврядування. В умовах децентралізації влади дедалі більше зростає роль професійного підходу до управління на місцевому рівні. Тут потрібно зауважити, що місцева влада - це єдиний механізм влади державної. Від їх взаємодії істотно залежить ефективний розвиток регіонів, міст, територіальних громад тощо. У практичному житті органи місцевого самоврядування не завжди готові до нових складних викликів сучасності. Саме в цьому проявляється несформованість управлінської культури керівників і управлінців на місцях. Тому констатуємо щодо загальних якостей та ознак управлінської культури: управлінці місцевого самоврядування мають формувати в себе глибокі знання і практичні навички вирішення місцевих соціальних, побутових, культурних тощо проблем, знати конкретні насущні питання пересічних простих людей, допомагати їм, не займатися політикою та маніпуляціями, а реально впроваджувати місцеві соціальні, економічні, культурні, бізнесові реформи і програми. Такими мають бути ремонт доріг, відкриття культурних і спортивних центрів, освітлення міст і сіл, збереження пам'ятників історії й архітектури, відновлення зеленої зони - парків, скверів, лісів, річок, озер, сприяння розвитку малого і середнього бізнесу, захист інтересів членів своїх територіальних громад, співпраця керівництва й громади тощо.

Важливим нині також видається такий напрям розвитку управлінської культури, який забезпечував би застосування найбільш новітніх досягнень у сфері публічного управління. 3 огляду на це варто зауважити, що формування управлінської культури на сучасному етапі має базуватися на новітніх соціальноуправлінських технологіях, що передбачають урахування всіх тих змін і реформ державного управління, що відбуваються. Серед таких нововведень можна назвати перехід до нової стадії публічного управління, створення умов для утвердження сервісної держави, пошук нових інноваційних управлінських методів 
роботи, покращення й вдосконалення системи публічних послуг, увагу до культурно-професійної складової частини управлінської діяльності тощо. Про такі сучасні підходи до розуміння публічного управління і ролі в ньому управлінської культури, які, власне, на часі, цього вимагає суспільна практика, пише український дослідник А. Рачинський [1]. Навіть більше, ми впевнені, що саме цей підхід сприятиме високій результативності в діяльності органів влади й управління всіх рівнів.

Отже, робимо висновки, що до перспективних досліджень галузі управління на сучасному етапі ми зараховуємо також відповідні новітні технології управління, що мають будуватися на принципах, якостях і нормах управлінської культури, які відповідали б цивілізованим методам публічного управління. Про це пишуть відомі дослідники цієї проблематики Д. Коттер і Б. Блум [2, с. 4].

Наприклад, спираючись на теорію управління змінами Д. Коттера, ми виділяємо вісім основних періодів або етапів управлінської діяльності, що засновані на певних нормах управлінської культури керівника й підлеглих:

- підготовка і створення умов для ефективних, невідкладних на цей момент практичних дій (організаційний складник управлінської культури - aвm.);

- формування єдиної, згуртованої реформаторської команди (ознака колективності управлінської культури - авт.);

- вироблення й рекламування нових управлінських дій і принципів роботи (результативність застосування нового бачення управління через норми і принципи управлінської культури - aвm.);

- створення умов для втілення цих нових дій та принципів у практичне управління (розуміння і толерантність у практичній управлінській роботі як якісна ознака управлінської культури - aвm.);

- закріплення уже здобутих результатів та не зупинятися на досягнутому (пошук нових форм управлінської роботи, сучасних підходів до формування управлінської культури - aвm.);

- планування найближчих, найбільш перспективних планів управлінської роботи (проводити певне планування, що призведе до більш успішного кінцевого результату управлінської роботи та ролі в ній управлінської культури - авт.);

- усі ці етапи перетворень необхідно інституціоналізувати і виробити нові моделі поведінки й культури управлінців (інституціоналізація управлінської культури як соціального інституту управлінського характеру - авт.);

- створення умов для подальшої успішної управлінської діяльності в недалекому майбутньому (прогнозування можливих процесів формування управлінської культури та iï значення у публічному управлінні - авт.) [3].

Б. Блум, досліджуючи поведінкові ефекти особистості у процесі пізнання, виокремлює п'ять, на його думку, етапів становлення управлінського керівника, які також засновані на деяких характеристиках управлінської культури:

- набуття знань основ управлінської науки (знання як один із найбільш вагомих чинників формування управлінської культури - авт.);

- розуміння як через знання приходять навички практичної управлінської роботи (взаємозв'язок теоретичних знань і практичних навичок в управлінській культурі керівника - aвm.);

- вміння у практичній роботі застосовувати ці знання й навики (знання й набуті навички мають призвести до вміння їх використовувати в повсякденній управлінській роботі - aвm.);

- здібність аналізувати свою управлінську діяльність (уміння аналізувати управлінську роботу, значення у формуванні управлінської культури такої ознаки, як аналітичні здібності - aвт.);

- імплементація та оцінка знань, які весь час мають поновлюватися й вдосконалюватися (постійне навчання, отримання нових знань та їх впровадження в практичну управлінську діяльність - aвт.) [4].

Початок XXI століття характерний також ще одним важливим для управлінської галузі моментом. Йдеться про взаємозв'язок теоретичних управлінських знань, застосування на їх основі новітніх управлінських технологій і поєднання всіх цих чинників у практичному публічному управлінні. Адже діяльність, що базується на знаннях й технологіях, постає однією з базисних засад управлінської роботи на основі культури. Усе це виступає важливою передумовою й свого роду гарантом успішних управлінських реформ державного управління та сучасних підходів до формування управлінської культури. Вірно пишуть Л. Штика, Н. Бондарчук і Л. Гогіна, що «формування нового суспільного статусу професійної діяльності державних службовців, зміна акцентуацій професійної свідомості - від чиновницької, розпорядчо-контролюючої, до усвідомленої підпорядкованості потребам замовника/ клієнта. У цьому сенсі праця набуває більш виражених професійних ознак, оскільки спрямовується не на процес, а на його результат, який оцінюється споживачем» [5, с. 14]. Названі зміни стимулюють управлінця до набуття нових рис професійної управлінської культури, яка характерна такими ознаками:

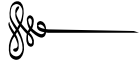


здорова ініціатива; здатність до впровадження інноваційних управлінських технологій; продуктивність і результативність управлінської діяльності; інноваційна активність; реальна відповідальність за прийняті рішення; творчість у роботі тощо. Такі ознаки професійної управлінської культури допоможуть та сприятимуть, на наше переконання, подальшому ефективному розвитку й впровадженню новітніх управлінських технологій і знань, а також результативній активізації працівників органів центральної та місцевої влади у своїй управлінській роботі.

Ще один важливий аспект публічного управління. Відомий американський дослідник управлінської діяльності Е. Шейн писав, що найважливішим досягненням практичного управління є «уміння викласти й донести максимально зрозуміло суть тієї проблемної ситуації, що має бути реалізована, а не прикриватися загальними словами про зміну культури» [6, с. 259]. Усе це потребує, на наш погляд, певних мотиваційних стимулів для успішності управлінської діяльності. А мотивація своєю чергою залежить і лежить у площині рівня управлінської культури. Серед мотиваційних стимулів ми хочемо виділити такі:

- соціалізаційні управлінські процеси від початку публічної служби, іншими словами, кожен самодостатній службовець має намагатися утвердитися і реалізуватися в соціумі;

- рівняння на якогось відомого авторитетного державного діяча, управлінця, свого роду ідентифікувати себе з ним, бути на нього схожим;

- здобуття влади та вплив на інших людей;

- удосконалення знань і навиків управлінської діяльності;

- повна реалізація своїх потенційних здібностей, постійний саморозвиток;

- раціональне використання реальних управлінських успіхів і практичних досягнень у роботі;

- усвідомлення відповідальності за свою управлінську діяльність;

- стосунки з іншими представниками управління;

- намагання уникати спірних рішень і не виправданих ситуацією управлінських дій. Про ці мотиваційні характеристики управлінської культури в управлінській діяльності пише С. Занюк [7, с. 21-30].

Нині важливими напрямами дослідження управлінської культури також виступають складні процеси управлінських змін, що відбуваються. Вони загалом не зовсім нові, оскільки вивчалися представниками управлінської думки раніше, але набули дещо інших форм і значення. Насамперед це кадрова проблема, коли управлінець із деякими ознаками і якостями управлінської культури розпочинає свою практичну роботу. До уже зазначених вище ознак і якостей управлінської діяльності хочемо додати моменти, що досліджувалися менше або не вивчалися зовсім.

Перше - це підбір управлінського персоналу, їх освітня специфіка. На сучасному етапі вона вимагає нових підходів і нового вибору. Управлінець має бути теоретично підготовленим, добре володіти знаннями як західної, так й української управлінської думки, навіть більше, самостійно навчатися, проходити перекваліфікацію з цього ремесла у таких спеціальних навчальних закладах, як НАДУ при Президентові України, ії філіях, ВНЗ, де функціонують управлінські факультети і кафедри, курси перекваліфікації управлінських кадрів тощо. Це дасть змогу мати професійних управлінців зі знаннями й практичними навичками управлінської роботи. Такі кроки призведуть, на наше переконання, до еволюційної зміни самої структури державного менеджменту, коли відбудуться осмислення й ототожнення управлінських принципів і методів, які будуть визначати результативність управління, глибокий аналіз ролі і значення управлінської культури, поглиблене вивчення організаційних проблем управління, усвідомлення індивідуальної й колективної відповідальності за окремо взяту людину, колектив, соціальну групу, за тих, хто є найбільш цінними в державі та суспільстві.

У цій роботі одне з найвагоміших значень набуває освіта управлінця, адже вона формує світобачення людини, її ставлення до оточуючого середовища, ставлення до людей і власне відповідальність за свої управлінські дії. Ми виділяємо такі, на нашу думку, найбільш важливі особливості освіти, які мають вплив на управлінську культуру (як нам видається, їх необхідно надалі досліджувати й знаходити нові моделі й форми):

- освіта виступає основою формування цінностей як суспільства, так і окремої людини, саме через освіту вона самостверджується й здобуває право на більш високий соціальний статус у суспільстві;

- освіта формує цінності управлінців, які беруть на себе відповідальність за управління державою та вирішення суспільних проблем. Для України такими цінностями, насамперед, мають бути порядність, чесність, вихованість, патріотизм, відповідальність, професіоналізм, нетолерантність до корупції тощо, що значно підвищить якість управління;

- освіта виступає консолідуючим чинником, що об'єднує громадянське суспільство, владу та бізнес, що своєю чергою призводить до підвищення рівня демократії та подолання конфліктів між вищезазначеними інститутами; 
- освіта є основою формування людського капіталу, який спроможний прискорювати розвиток держави і суспільства;

- освіта виступає фундаментом економічної, політичної, соціальної та військової могутності держави через формування цінностей суспільства та людського капіталу;

- освіта сприяє розбудові громадянського суспільства, що призводить до підвищення рівня демократії та дієвої свідомої участі громадян у процесах прийняття рішень;

- освіта є одним із чинників сприяння сталому розвитку держави;

- освіта виступає дієвим засобом управління суспільством та суспільною свідомістю на користь держави [8, с. 61]. Усе це наводить на думку, що освіта має виступати провідним чинником формування й утвердження управлінської культури.

Отже, освіта, практичні кроки й теоретико-методологічне забезпечення сприятимуть процесам формування й сучасного вдосконалення якостей та ознак управлінської культури. Серед найважливіших критеріїв формування й вдосконалення управлінської культури варто виділити такі: вміння управлінця вести діалог, не тільки доводити свою позицію, але й слухати, а найголовніше, розуміти людей; значимість лідерських якостей управлінців; управлінський професіоналізм у роботі; удосконалення навичок, умінь і знань для досягнення вагомих результатів управлінської діяльності; морально-етичні якості, естетичні вподобання тощо. Сучасні соціально-технологічні підходи до розвитку управлінської культури в Україні тісно переплітаються і взаємопов'язані з реорганізацією державного управління, подальшим становленням громадянського суспільства як повноцінного учасника публічної політики та управління суспільством і державою. I тут важливо зауважити про зародження й розвиток в Україні певної моделі стратегічного впливу управлінської культури на формування нових принципів, ознак, норм, цінностей управлінців в їхній професійній діяльності. Вона, перш за все, має переключитися на людину і для людини, більш результативнішою має стати сфера якісних послуг.

Ще одним важливим й актуальним нині аспектом дослідження управлінської культури виступає визначення їі ролі та місця у вирішенні проблеми корупції в управлінській сфері діяльності. В Україні склалася ситуація, коли корупція, ії схеми охопили майже всі галузі суспільного життя. У політиці політична корупція, в освіті й науці - своя корупція, в управлінні як на державному, так і місцевому рівні - корупція по відбору кадрів, призначення на так звані «теплі» місця, в медицині без знайомства й певної грошової взятки не візьмуть на постійну роботу і т. п. Поступово корупція перетворюється на корозію повсякденного життя, вона стає вигідною, і такий стан речей найстрашніший та найнебезпечніший. Через це ми поступово стаємо суспільством загального ризику, де корупція породжує ненависть, злість, заздрість, брехню, наглість, демагогію, жадібність, неповагу до людини, гроші понад усе та ін. Усе це наштовхує на думку, як правильно наголошує О. Пархоменко-Куцевіл, що «в Україні виникла нагальна потреба розробки Концепції формування антикорупційної культури» [9, с. 96]. Вона (Концепція) має складатися, на нашу думку, з двох взаємопов'язаних етапів.

Перший етап можна назвати освітнім, просвітницьким. Він розпочинається зі школи, де варто ввести навчання з основ антикорупційної освіти, до прикладу, читаючи їі як складник права або, як нам видається перспективнішим, окрему навчальну програму. Далі така дисципліна має викладатися в коледжах, вищих професійно-технічних училищах, а особливо вищих навчальних закладах, коли молода людина переходить до фази вторинної соціалізації і вступає в самостійне суспільне життя. Другий етап - формування антикорупційної культури в управлінській діяльності, особливо політиків, менеджерів високого рівня, керівників і працівників місцевого самоврядування, публічних службовців тощо. I тут важливого значення набувають антикорупційна освіта, що була сформована на першому етапі, а також позитивні якості управлінської культури управлінця: чесність, принциповість, системність і послідовність дій, вміння підібрати професійних працівників, морально-етичні норми і цінності тощо.

Таким чином, підбиваючи підсумки дослідження управлінської культури, іiі наукових витоків та подальших напрямів формування, можна сказати, що завдання ці надзвичайно складні, вимагають кропіткої роботи, часу, знаходження нових методів і форм роботи, кадрового забезпечення, великих фінансів, зміни самої системи державного управління і т. д. Певні кроки в цих напрямах уже робляться. Зокрема, по проблемах корупції, але вони, на жаль, не результативні. Прикладом можна назвати тезу, що управлінці, менеджери, політики, представники виконавчих органів влади мають отримувати надзвичайно високу зарплатню, тобто фінансово бути достатніми і тоді жодних корупційних дій з їхнього боку не буде. Практика показала, що, незважаючи на захмарні виплати й премії, корупція в названих сферах суспільного життя продовжується й процвітає. Вважаємо, необхідно шукати інші форми, інші підходи в цій роботі. I одним із таких варіантів $є$, на наш погляд, формування антикорупційної культури, яка є складником культури управління починаючи зі шкільних років. Якщо майбутній політик,

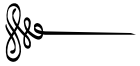


менеджер, управлінець зі шкільних років усвідомив, що корупція поступово знищує державні інституції, не дає успішно розвиватися громадянському суспільству, руйнує сім’і й людей, то надалі він, як думається, все буде робити для того, щоб такого соціального явища, як корупція, не існувало. Це стане певним чином виховним процесом життя, його антикорупційним менталітетом, який базуватиметься на психологічному й моральному рівнях.

Тема залишається відкритою для наукових дискусій, адже життя не стоїть на місці. Змінюються погляди і думки, робляться нові практичні кроки в публічному управлінні, а це вимагає подальших розвідок проблематики управлінської культури. Вона для сучасних управлінців має стати виміром їхнього життєвого кредо - успішне результативне управління для людей і на благо людей. Адже цивілізоване публічне управління спрямоване на найдорожчий соціальний капітал - людину.

\section{Література:}

1. Рачинський А.П. Організаційна структура і стратегічне управління персоналом: особливості взаємозв'язку. URL: http://www.nbuv.gov.ua/e-journals/2007-1.

2. Гошовська В.А., Даниленко Л.І. Інструментальний підхід до розвитку лідерства публічних службовців України. Інституиіоналізація публічного управління в Украӥні в умовах євроінтеграчійних та глобалізаиійних викликів : матеріали щоріч. Всеукр. наук.-практ. конф. за міжнар. участю: у 5 т. / за заг. ред. А.П. Савкова, М.М. Білинської, О.М. Петроє. Київ: НАДУ, 2019. Т. 5. С. 3-5.

3. Джон Коттер и Ko. URL: http://ibcm.biz

4. Таксономія Блума. URL: https://uk.wikipedia.org/wiki

5. Професіоналізація державної служби / Л.Г. Штика, Н.О. Бондарчук, Л.М. Гогіна та ін. Київ : НАДУ, 2008. 36 с.

6. Шейн Э. Организационная культура и лидерство: 3-е изд. / пер. с англ., под ред. Т.Ю. Ковалёвой. Санкт-Петербург : Питер, 2007. $338 \mathrm{c}$.

7. Занюк С. Психологія мотивації. Київ : Либидь, 2002. 304 с.

8. Liliia V. Honiukova, Vitaliy I. Dokash, Volodymyr V. Perzhun, Nadiia O. Chyrkova. Educational Imperatives of the Administrative Culture in Ukraine: An Empirical Approach. International Journal of Innovation, Creativiry and Change. Volume 12, Issue 10, 2020. P. 54-66.

9. Пархоменко-Куцевіл О.І. Проблеми формування антикорупційної культури як основи формування ефективних механізмів запобігання корупції. Інституиіоналізаиія публічного управління в Україні в умовах євроінтеграційних та глобалізаційних викликів : матеріали щоріч. Всеукр. наук.-практ. конф. за міжнар. участю: у 5 т. / за заг. ред. А.П. Савкова, М.М. Білинської, О.М. Петроє. Київ : НАДУ, 2019. Т. 1. С. 95-96. 